\title{
ANALISIS MINAT BELAJAR SELAMA PANDEMI COVID-19 DI LINGKUNGAN III KELURAHAN PADANG MASIANG KECAMATAN BARUS
}

\author{
Oleh : \\ Saripahtul Khairah Pohan'), Tamin Ritonga ${ }^{2)}$, Roslian Lubis ${ }^{3)}$ \\ ${ }^{1,3}$ Fakultas MIPA, Institut Pendidikan Tapanuli Selatan \\ ${ }^{2}$ Fakultas IPSB, Institut Pendidikan Tapanuli Selatan
}

\begin{abstract}
Abstrak
Penelitian ini dilatarbelakangi oleh adanya wabah Covid-19 di dunia yang menyebabkan krisis kesehatan global. Masalah ini membuat kebijakan untuk mengubah pembelajaran offline menjadi online. Berdasarkan situasi tersebut, peneliti tertarik untuk mendeskripsikan minat belajar siswa SMP di Lingkungan III Kelurahan Padang Masiang Kecamatan Barus. Pendekatan penelitian ini menggunakan deskriptif kualitatif dan subjek penelitian adalah siswa SMP di Lingkungan III Kelurahan Padang Masiang. Kuisioner dan wawancara digunakan untuk mengumpulkan data. Hasil angket menunjukkan minat belajar siswa adalah 50\% berminat cukup, $40 \%$ berminat kurang, dan $10 \%$ berminat. Lebih lanjut, hasil wawancara dengan orang tua menunjukkan minat belajar siswa kurang berminat dan wawancara dengan guru menunjukkan minat belajar cukup diminati.
\end{abstract}

\section{Kata kunci : minat belajar, pembelajaran matematika, Covid-19}

\begin{abstract}
The background of this research is Covid- 19 pandemic in world that caused global health crisis. This problem made a policy to change offline learning to online. Based on the situation, the researcher is interested to describe the interest learning of students at Junior High School in Lingkungan III Kelurahan Padang Masiang, Barus sub-district. The approach of this research used qualitative descriptive and subject of the research is students of SMP in Lingkungan III Kelurahan Padang Masiang. Questionnaire and interview were used in collecting the data. The result of questionnaire shows 50\% in enough interested, $40 \%$ in poor interested, and $10 \%$ in interested. Furthermore, the result of interview of parents show in poor interested and interview of teacher shows in enough interested.
\end{abstract}

\section{Keywords : learning interest, mathematic learning, Covid-19}

\section{PENDAHULUAN}

Pada saat ini, dunia kini diresahkan dengan adanya wabah Corona Virus Disease (COVID-19) yang menjadi sebuah pandemi. Seluruh dunia kini disibukkan dengan berbagai upaya pencegahan COVID-19 menahan lonjakan pasien positif karena hingga saat ini belum ditemukan obat maupun vaksinnya. Pandemi ini terjadi pula di Indonesia yang membuat banyak pihak berupaya ikut serta dalam mengatasinya. Salah satu dampak pandemi COVID-19 ialah terhadap pendidikan di seluruh dunia yang mengarah kepada penutupan sekolah, madrasah, dan universitas. Pandemi adalah skala penyebaran penyakit yang terjadi secara global diseluruh dunia. Sementara Organisasi Kesehatan Dunia (WHO) mengartikan pandemi sebagai penyebaran penyakit baru ditingkat dunia. COVID-19 merupakan penyakit menular yang disebabkan oleh sindrom pernapasan akut coronavirus 2 (severe acute respiratory syndrome coronavirus 2 atau SARS-CoV-2).

Situasi saat ini pula menuntut para guru dan siswa untuk bekerja dan belajar dari rumah. Proses pembelajaran yang tertunda memungkinkan minat siswa dalam belajar menurun yang akan menghambat perkembangan belajar siswa. Minat pada dasarnya merupakan perhatian yang bersifat khusus. Siswa yang menaruh minat pada suatu pelajaran perhatian akan tinggi dan minatnya berfungsi sebagai pendorong kuat untuk terlibat aktif dalam kegiatan belajar mengajar. Belajar merupakan proses sadar dari perkembangan pengetahuan dan pribadi manusia, melalui belajar manusia dapat melakukan perubahanperubahan dan menghasilkan prestasi yang berguna bagi kehidupan manusia.

Minat belajar besar sekali pengaruhnya terhadap hasil belajar sebab dengan minat seseorang akan melakukan sesuatu yang diminatinya. Sebaliknya tanpa minat seseorang tidak mungkin melakukan sesuatu. Dengan adanya pandemi COVID-19, tentunya minat belajar siswa tidak seperti biasanya. Tugas 
ISSN. 2621-9832

JURNAL MathEdu (Mathematic Education Journal) http://journal.ipts.ac.id/index.php/MathEdu Vol. 4 No. 2 Juli 2021

sekolah, kondisi lingkungan dan media pembelajaran yang saat ini memaksa siswa untuk mampu beradaptasi dari awal lagi. Terlebih lagi ketakutan-ketakutan yang disebabkan oleh virus yang membuat konsentrasi dan daya ingat siswa menurun. Keadaan rumah dan keluarga juga dapat mempengaruhi minat seorang siswa suasana keluarga yang tenang, damai, tentram dan menyenangkan akan mendukung minat siswa dalam belajar dirumah. Oleh karena itu peneliti tertarik mengangkat judul analisis minat belajar siswa selama pandemi COVID-19 di Lingkungan III Kelurahan Padang Masiang Kecamatan Barus.

\section{HAKIKAT MINAT BELAJAR}

Slameto dalam Simbolon (2010:180) mengatakan "Minat adalah suatu rasa lebih suka dan rasa kaitan pada suatu hal atau aktivitas, tanpa ada yang menyuruh". Menurut Lestari (Sardiman, 2007:77) mengatakan "Minat adalah suatu kondisi yang terjadi apabila seseorang memiliki ciri-ciri atau arti sementara situasi yang dihubungkan dengan keinginan- keinginan atau kebutuhan-kebutuhan sendiri". Riyanto (Walker, 2012:5) menyatakan "Belajar adalah suatu perubahan dalam pelaksaan tugas yang terjadi sebagai hasil dari pengalaman dan tidak ada sangkut pautnya dengan kematangan rohaniah, kelelahan, motivasi, perubahan dalam situasi stimulus atau faktor-faktor samar lainnya yang tidak berhubungan langsung dengan kegiatan belajar". Menurut Suyono (2011:9) dalam Simbolon (2013:15) menyatakan "Belajar dalah suatu aktivitas atau suatu proses untuk memperoleh pengetahuan meningkatkan keterampilan, memperbaiki perilaku, sikap dan memperkokoh kepribadian". Menurut Slameto (2015:2) menyatakan "Belajar ialah suatu proses yang dilakukan seseorang untuk memperoleh suatu perubahan tingkah laku yang baru secara keseluruhan, sebagai hasil pengalamannya sendiri dalam interaksi dengan lingkungannya".

Berdasarkan beberapa pendapat ahli diatas penulis menyimpulkan belajar adalah suatu usaha yang dilakukan untuk tujuan perubahna tingkah laku individu melalui interaksi dengan lingkungan pengalaman belajarnya. Belajar merupakan proses internal yang kompleks, yang terlibat dalam proses internal tersebut adalah seluruh mental yang meliputi ranah-ranah kognitif, afektif, dan psikomotorik.

Minat belajar merupakan sebagai keinginan dan keterlibatan yang disengaja dalam aktivitas kognitif yang memainkan bagian penting dalam proses pembelajaran, menentukan bagian apa yang kita pilih untuk belajar dan seberapa baik kita mempelajari informasi yang diberikan. Menurut Nurhasanah, Sobandi (Olivia, 2016:130) menyatakan "Minat belajar adalah sikap ketaatan pada kegiatan belajar, baik menyangkut perencanaan jadwal belajar maupun inisiatif melakukan usaha tersebut dengan sungguhsungguh". Menurut Marimba dalam Ricardo dan Rini (2017:190) menyatakan "Minat belajar adalah kecendrungan jiwa untuk mendapatkan sesuatu karena siswa tersebut merasakan hal yang menarik dalam belajar, yang umumnya ditandai dengan perasaan tenang". Menurut Slameto dalam Ricardo dan Rini (2017:190) menyatakan "Minat belajar merupakan suatu rasa untuk menyukai atau tidak tertarik pada suatu hal atau aktivitas belajar tanpa ada yang menyuruh".

Berdasarkan beberapa pendapat para ahli diatas penulis menyimpulkan bahwa minat belajar merupakan faktor pendororng siswa dalam belajar yang didasari atas rasa ketertarikan atau rasa senang dan keinginan siswa untuk belajar. Minat belajar juga merupakan aspek pembangun motivasi, yang terbentuk akibat interaksi sosial dan keterlibatan siswa dalam kegiatan belajar.

Safari dalam Ricardo dan Meilani (2017:190) ada beberapa indikator yang digunakan untuk mengukur minat belajar siswa untuk belajar, yaitu: perhatian, ketertarikan, rasa senang dan keterlibatan. Menurut Renninger, dkk dalam Ricardo dan Meilani (2017:190) mengungkapkan ada beberapa hal yang menggambarkan minat belajar siswa, seperti adanya perhatian dan konsentrasi yang lebih besar, perasaan senang untuk belajar, dan adanya peningkatan kemauan untuk belajar. Menurut Slameto dalam Nurhasanah dan Sobandi (2016:130-131), diantaranya yaitu: ketertarikan untuk belajar, perhatian dalam belajar, motivasi belajar dan pengetahuan.

1. Ketertarikan untuk belajar

Ketertarikan untuk belajar diartikan apabila seseorang yang berminat terhadap suatu pelajaran maka ia akan memiliki perasaan ketertarikan terhadap pelajaran tersebut. Siswa akan rajin dan terus memiliki perasaan ketertarikan terhadap pelajaran tersebut, siswa akan mengikuti pelajaran dengan penuh antusian tanpa ada beban sedikit pun.

2. Perhatian dalam belajar

Perhatian merupakan konsentrasi atau aktivitas jiwa seseorang terhadap pengamatan, pengertian ataupun yang lainnya dengan mengesampingkan hal lain dari pada itu. Jadi, siswa akan mempunyai perhatian dalam belajar, jika jiwa dan pikirannya terfokus dengan apa yang siswa pelajari.

3. Motivasi belajar

Motivasi merupakan suatu usaha atau pendorong yangdilakukan secara sadar untuk 
ISSN. 2621-9832

JURNAL MathEdu (Mathematic Education Journal) http://journal.ipts.ac.id/index.php/MathEdu

Vol. 4 No. 2 Juli 2021

melakukan tindakan belajar dan mewujudkan perilaku yang terarah demi pencapaian tujuan yang diharapkan dalam situasi interaksi belajar.

4. Pengetahuan

Pengertian diartikan bahwa jika seseorang yang berminat terhadap suatu pelajaran maka akan mempunyai pengetahuan yang luas tentang pelajaran tersebut serta bagaimana manfaat belajar dalam kehidupan sehari-hari.

Berdasarkan beberapa pendapat ahli diatas peneliti menggunakan 4 indikator, yaitu ketertarikan dalam belajar, perhatian dalam belajar, motivasi belajar, dan pengetahuan. Minat belajar merupakan faktor pendorong siswa dalam belajar yang didasari atas ketertarikan atau rasa senang dan keinginan siswa untuk belajar.

\section{Hakekat Pandemi COVID-19}

Pakpahan, Fitriani (2020:32) mengatakan: "Corona virus merupakan keluarga besar virus yang menyebabkan penyakit pada manusia dan hewan. COVID-19 merupakan penyakit menular yang disebabkan oleh sindrom pernapasan akut corona virus 2 (severce acute respiratory syndrome coronavirur 2 atau SARS-Co V-2). Ketika menyerang manusia, corona virus biasanya menyebabkan penyakit infeksi saluran pernapasan, seperti MERS (Middlme East Respiratory Syndrome) dan SARS (Severe Acute Respiratory Syndrome). Infeksi virus umumnya dikaitkan dengan infeksi saluran pernapasan bagian atas, yang tanda dan gejalanya biasanya meliputi demam, sakit kepala, dan batuk, beberapa pasien mungkin memiliki infeksi saluran pernapasan bawah". Menurut Setiawan (2020:29) mengatakan:“Covid-19 merupakan penyakit menular yang disebabkan oleh sindrom pernapasan akut corona virus 2 (severe acute respiratory syndroe coronavirus 2). Virus ini merupakan keluarga besar Coronavirus yang dapat menyerang hewan. Ketika menyerang manusia, coronavirus biasanya menyebabkan penyakit infeksi saluran pernapasan, seperti flu, MERS, dan SARS”. Berdasarkan beberapa pendapat ahli diatas penulis menyimpulkan covid 19 adalah penyakit yang disebabkan oleh virus yang dapat menyerang manusia dan hewan. Penyakit yang disebabkan seperti infeksi saluran pernapasan seperti flu, yang tanda dan gejalanya biasanya meliputi demam, sakit kepala, dan batuk.

\section{Bahaya Covid-19}

Peningkatan jumlah kasus terjadi dalam waktu singkat hingga butuh penganan secepatnya. Memiliki gejala yang sama-sama mirip flu, virus corona berkembang cepat hingga mangakibatkan infeksi lebih parah dan gagal organ. Gejala ringan kasus infeksi virus corona arau covid-19: a. Batuk, b. Letih, c. Sesak napas dan ngilu di seluruh tubuh, d. Secara umum merasa tidak enak badan. Pada kasus yang lebih parah, infeksi covid-19 bisa menyebabkan beberapa komplikasi berikut ini: a. Pneumonia (ingeksi paruparu), b. Infeksi sekunder pada organ lain, c. Gagal ginjal, d. Acute cardiac injuiry. e. Acute respiratory distress syndrome, d. Kematian.

Pada beberapa orang, penyakit ini dapat berkembang menjadi infeksi paru-paru, kegagalan multi organ, dan kematian. Pada beberapa orang covid-19 dapat mempengaruhi paru-paru yang menyebabkan pneumonia (infeksi paru-paru). Mereka yang paling parah terkena dampaknya, covid-19 dapat dengan cepat berkembang menjadi sindrom gangguan pernapasan akut (ARDS) yang menyebabkan kegagalan pernapasan atau kegagalan multi-organ. Komplikasi yang terkait dengan covid-19 termasuk sepsis, pembekuan abnormal, dan kerusakan pada jantung, ginjal, dan hati.

\section{Penularan Covid-19}

Virus corona bisa berada dimana saja, menempel dibenda-benda yang ada disekitar kita. Penyakit ini menyebar selama kontak dekat, seringkali oleh tetesan kecil yang dihasilkan selam batuk, bersin atau berbicara. Tetesan ditularkan, dan menyebabkan infeksi baru, ketika dihirup oleh orang-orang dalam kontak dekat 1 hingga 2 meter. Virus tersebut diproduksi selama bernapas, namun karena virus relatif berat, virus tersebut jatuh ketanah atau permukaan. Penularan covid-19 tidak langsung terjadi. Penularan itu dapat terjadi melalui benda sekitar kita yang tercemar virus yang kita sentuh dan kemuadian menyentuh mulut, hidung, dan wajah. Menurut dr. Ahmat Yerianto "Seseorang yang membawa virus dalam tubuhnya dan tidak memakai masker, maka oarang disekitarnya memiliki resiko tertular sampai 75\% karena percikan dari ludah mengenai banyak benda". Ciri-ciri atau gejala covid-19 kebanyakan muncul 2-10 hari setelah kontak dengan virus. Tapi pada beberapa kasus, ciri-ciri awal corona virus dan gejalanya baru muncul sekitar 24 hari. Untuk membedakan ciri-ciri awal corona dan flu biasa, ada beberapa hal yang harus diperhatikan, yaitu:

a. Dalam 14 hari sempat bepergian ke negara yang di anggap sumber virus corona

b. Sempat kontak dengan pasien yang mengalami infeksi corona. 


\section{METODE PENELITIAN}

Metode penelitian dalam penelitian ini menggunakan metode penelitian kualitatif. Penelitian kualitatif adalah suatu penelitian yang dilakukan untuk mendapatkan pemahaman yang lebih luas dan mendalam terhadap situasi sosial pendidikan. Menurut Bogdan dan Taylor dalam Rangkuti (2014:18) mengemukakan "Metode kualitatif sebagai prosedur penelitian yang menghasilkan data deskriftif berupa kata-kata atau lisan dari orang-orang dan perilaku yang dapat diamati”.

\section{a. Objek dan Informan Penelitian}

Objek dalam penelitian ini yaitu analisis minat belajar siswa selama pandemi COVID-19. Informan dalam penelitian ini adalah guru dan siswa SMP berjumlah 10 siswa yang bertempat tinggal di Lingkungan III kelurahan Padang Masiang.

\section{b. Data dan Sumber Data}

Data adalah segala fakta dan angka yang dapat dijadikan bahan untuk menyusun suatu informasi, data yang diperoleh nantinya diolah sehingga menjadi informasi yang lebih baru. sumber data primer dalam penelitian ini adalah siswa itu sendiri, Sedangkan, sumber data primer yang diperoleh baik dari buku pendidikan dan jurnal pendidikan.

\section{c. Teknik Pengumpulan Data}

1. Wawancara

Arikunto (2017:186) mengatakan "Wawancara adalah percakapan dengan maksud tertentu". Menurut Sugiyono (2018:194) "Wawancara digunakan sebagai teknik pengumpulan data apabila ingin melakukan studi pendahuluan untuk menemukan permasalahan yang diteliti, dan juga apabila peneliti ingin mengetahui hal-hal dari responden yang lebih mendalam dan jumlah respondennya sedikit/kecil". Dalam penelitian ini peneliti menggunakan wawancara terstruktur. Wawancara terstruktur dilakukan peneliti dengan menyiapkan pertanyaan-pertanyaan tertulis yang telah disediakan. Dengan wawancara terstruktur ini responden diberi pertanyaan yang sama dan pengumpul data mencatat setiap jawaban dari setiap responden.

2. Angket

Angket adalah teknik pengumpulan data yang digunakan penenliti untuk mengumpulkan data dengan cara menyebarkan sejumlah lembar kertas yang berisi pertanyaan-pertanyaan yang harus dijawab responden.

Table 1

\begin{tabular}{clcc} 
No. & \multicolumn{1}{c}{$\begin{array}{c}\text { Kisi-kisi Indikator Minat Belajar Siswa } \\
\text { Indikator }\end{array}$} & $\begin{array}{c}\text { Item } \\
\text { Pernyataan }\end{array}$ & $\begin{array}{c}\text { Banyak } \\
\text { Pernyataan }\end{array}$ \\
\hline 1 & Ketertarikan untuk belajar & $1,2,3,4$ & 4 \\
\hline 2. & Perhatian dalam belajar & $5,6,7,8$ & 4 \\
\hline 3. & Motivasi belajar & $9,10,11$ & 3 \\
\hline 4. & Pengetahuan & $12,13,14,15$ & 4 \\
\hline & Jumlah & & $\mathbf{1 5}$
\end{tabular}

Peneliti ini menggunakan skala Guttman dalam penelitian ini, yaitu dengan jawaban "Ya" dan "Tidak", dengan perhitungan $\mathrm{Ya}=1$, Tidak $=0$. Instrumen penelitian yang menggunakan skala guttman dapat dibuat dalam bentuk cheklis.

$$
\text { Nilai akhir }=\frac{\text { Jumlah Skor yang dipeoleh }}{\text { jumlah Skor Maksimal }} \text { X } 100
$$

\section{d. Teknik Keabsahan Data}

Untuk mengukur tingkat kepercayaan (kredibilitas) penelitian kualitatif sehingga dapat dipertanggunjawabkan secara ilmiah. Pengukuran keabsahan data pada penelitian ini dilakukan dengan triangulasi.

\section{e. Teknik Analisis Data}

1. Reduksi Data

Reduksi data merupakan proses berpikir sensitif yang memerlukan kecerdasan dan keluasan dan kedalaman wawasan yang tinggi Menurut Sugiyono (2018:338) mengatakan "Mereduksi data berarti merangkum, memilih hal-hal yang pokok, memfokuskan pada hal-hal yang penting, dicari tema dan polanya dan membuang yang tidak perlu". Menurut Rangkuti (2014:156) mengatakan "Mereduksi data 
ISSN. 2621-9832

JURNAL MathEdu (Mathematic Education Journal) http://journal.ipts.ac.id/index.php/MathEdu

Vol. 4 No. 2 Juli 2021

berarti merangkum, memilih hal-hal yang pokok, memfokuskan pada hal-hal yang penting, dicari tema dan polanya dan membuang yang tidak perlu". Menurut Silalahi (2012:339) mengatakan "Reduksi data diartikan sebagai proses pemilihan, pemusatan perhatian pada penyederhanaan, pengabstraksian, dan trasformasi data kasar yang muncul dari catatan-catatan tertulis dilapangan".

2. Penyajian Data

Rangkuti (2014:157) mengatakan "Data display didefinisikan juga sebagai data organized, suatu cara pengkompresan informasi yang memungkinkan suatu kesimpulan atau tindakan diambil sebagai bagian dari analisis". Miles dan Huberman (2002) dalam Nizar (2014:157) mengatakan "Dengan mendisplaykan data, maka akan memudahkan untuk memahami apa yang terjadi, merencanakan kerja selanjutnya berdasarkan apa yang telah dipahami tersebut".

Menurut Silalahi (2012:340) mengatakan "Penyajian data adalah sekumpulan data informasi tersusun yang memberi kemungkinan adanya penarikan kesimpulan dan pengambilan tindakan".

3. Kesimpulan dan Verifikasi Data

Sugiyono (2018:345) mengatakan "Kesimpulan dalam penelitian kualitatif yang diharapkan adalah temuan baru yang sebelumnya belum pernah ada. Temuan dapat berupa deskripsi atau gambaran obyek yang sebelumnya masih reman-remang atau gelap sehinga setelah diteliti menjad jelas". Menurut Rangkuti (2014:158) mengatakan "Kesimpulan dan verifikasi data merupakan tindakan penelitian dalam menginterpretasikan data, menggambarkan makna dari data display”.

\section{HASIL DAN PEMBAHASAN TEMUAN UMUM}

Barus adalah sebuah kecamatan di kabupaten Tapanuli Tengah, Sumatera Utara, indonesia. Ibu kota kecamatan ini berada di kelurahan Padang Masiang. Padang Masiang adalah kelurahan yang berada di kecamatan Barus, Kabupaten Tapanuli Tengah, Sumatera Utara yang dipimpin oleh camat Wirdan Pasaribu,S.Pd.I. Penelitian dilakukan di lingkungan III kelurahan Padang Masiang kecamatan Barus yang berada di Kabupaten Tapanuli Tengah Provinsi Sumatera Utara, yang dipimpin oleh lurah Sofiana Martini Sinaga, S.H, M.A.P yang memiliki penduduk pada tahun 2020 berjumlah 2.587 jiwa. Kelurahan Padang Masiang adalah kelurahan yang mata pencaharian masyarakat bertani, nelayan, dan buruh kasar kategori masyarakat menengah kebawah. Kelurahan Padang Masiang terdiri dari 5 lingkungan yang berbeda-beda yaitu lingkungan I, Lingkungan II, lingkungan III, lingkungan IV dan Lingkungan V. Lingkungan III kelurahan Padang Masiang ini juga salah satu desa yang terkena dampak pandemi covid19 sehingga siswa yang berada di lingkungan III melaksanakan pembelajaran sesuai dengan protokol kesehatan sesuai dengan peraturan sekolah masing-masing.

\section{TEMUAN KHUSUS}

Hasil angket yang dibagikan kepada siswa SMP di Lingkungan III kelurahan Padang Masiang. Setelah peneliti membagikan angket kepada siswa dengan 15 item pernyataan, maka peneliti mengambil 3 perwakilan dari 10 siswa untuk dijabarkan yaitu siswa yang berkategori "kurang berminat", "cukup berminat", dan "berminat". Angket yang dibagikan siswa hanya menceklis jawaban "Ya" dan "Tidak" sesuai dengan keadaan yang dialami siswa tentang minat belajar selama pandemi covid-19. Setelah pemberian angket kemudian dilakukan wawancara dengan 3 orang siswa, orang tua siswa, dan guru matemtika.

\section{Hasil Jawaban Angket}

Penyebaran angket ini dilakukan pada tanggal 27 Februari 2021, informan penelitian dalam penelitian ini sebanyak 10 orang siswa SMP.

Tabel 2

Kriteria Penilaian Angket Minat Belajar Siswa Selama Pandemi Covid-19 di Lingkungan III Kelurahan Padang Masiang Kecamtan Barus

\begin{tabular}{|c|c|c|c|c|c|c|c|}
\hline \multirow[b]{2}{*}{ No } & \multirow[b]{2}{*}{$\begin{array}{l}\text { Nama } \\
\text { siswa }\end{array}$} & \multirow[b]{2}{*}{$\mathrm{Jb} / \mathbf{N} \times 100$} & \multicolumn{5}{|c|}{ Kriteria Penilaian } \\
\hline & & & $\begin{array}{c}\mathbf{0 - 2 0} \\
\text { (Tb) }\end{array}$ & $\begin{array}{c}21-40 \\
(\mathrm{~Kb})\end{array}$ & $\begin{array}{c}41-60 \\
(\mathrm{Cb})\end{array}$ & $\begin{array}{c}61-80 \\
\text { (B) }\end{array}$ & $\begin{array}{c}\text { 81-100 } \\
\text { (Sb) }\end{array}$ \\
\hline 1. & AM & $6 / 15 \times 100=40$ & & $\checkmark$ & & & \\
\hline 2. & AS & $9 / 15 \times 100=60$ & & & $\checkmark$ & & \\
\hline 3. & DA & $5 / 15 \times 100=33$ & & $\checkmark$ & & & \\
\hline 4. & $\mathrm{DL}$ & $9 / 20 \times 100=60$ & & & $\checkmark$ & & \\
\hline 5. & DS & $7 / 15 \times 100=47$ & & & $\checkmark$ & & \\
\hline
\end{tabular}




\begin{tabular}{ccccc}
\hline 6. & FS & $10 / 15 \times 100=67$ & & $\checkmark$ \\
\hline 7. & JA & $8 / 15 \times 100=53$ & $\checkmark$ & \\
\hline 8. & PS & $6 / 15 \times 100=40$ & & $\checkmark$ \\
\hline 9. & RF & $7 / 15 \times 100=47$ & $\checkmark$ & \\
\hline 10 & SM & $5 / 15 \times 100=33$ & Tabel 3
\end{tabular}

Hasil Jawaban Angket Minat Belajar Siswa Selama Pandemi Covid-19 di Lingkungan III Kelurahan Padang Masiang Kecamtan Barus No Nama siswa Keterangan

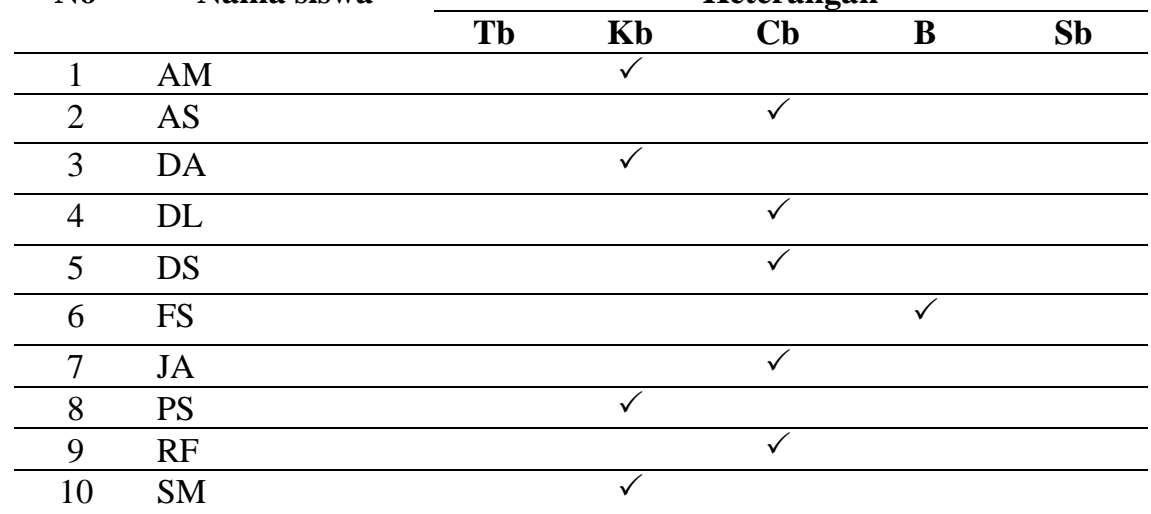

Table 4

Hasil Jawaban Yang Diperoleh Dari Penyebaran Angket Tentang Minat Belajar Siswa Selama Pandemi Covid-19 di Lingkungan III Kelurahan Padang Masiang Kecamtan Barus

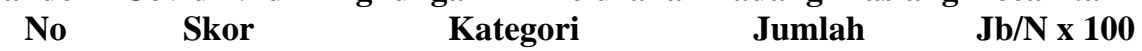

\begin{tabular}{ccccc}
\hline 1 & $0-20$ & Tidak Berminat & 0 & 0 \\
\hline 2 & $21-40$ & Kurang Berminat & 4 & 40 \\
\hline 3 & $41-60$ & Cukup Berminat & 5 & 50 \\
\hline 4 & $61-80$ & Berminat & 1 & 10 \\
\hline 5 & $81-100$ & Sangat Berminat & 0 & 0 \\
\hline & Jumlah & & $\mathbf{1 0}$ & $\mathbf{1 0 0}$
\end{tabular}

Berdasarkan dari hasil tabel jawaban yang diperoleh dari penyebaran angket tentang minat belajar siswa selama pandemi covid-19 diketahui dari angket pada kategori tidak berminat menjawab 0, kategori kurang berminat menjawab sebanyak 4 orang dari total item pernyataan sebanyak 15 atau 40 masuk dalam kategori kurang berminat, kategori cukup termotivasi menjawab sebanyak 5 orang dari total item pernyataan sebanyak 15 atau 50 masuk dalam kategori cukup berminat, kategori berminat menjawab sebanyak 1 orang atau 10 masuk dalam kategori berminat, dan kategori sangat berminat menjawab 0 . Dengan demikian dapat disimpulkan bahwa minat belajar siswa selama pandemi covid-19 di lingkungan III kelurahan Padang Masiang kecamatan Barus masuk dalam kategori cukup berminat. Yang artinya didaerah ini masih banyak kesulitan dalam membuat siswa berminat dalam pembelajaran daring hal ini senada dengan penelitian Simanjuntak, dkk (2020) yang menjelaskan bahwa kesulitan belajar siswa pada saat pembelajaran daring masihlah banyak utamanya masalah minat siswa itu sendiri.

\section{KESIMPULAN}

Gambaran dari hasil penelitian yang dilakukan dapat disimpulkan bahwa minat belajar siswa selama pandemi covid-19 di Lingkungan III kelurahan Padang Masiang 50\% masuk dalam kategori cukup berminat menjawab sebanyak 5 orang disebabkan oleh mereka sering membaca buku pelajaran dan senang belajar dengan guru matematika, materi pelajaran matematika bagi mereka sangat sulit, rumus matematika bukanlah hal yang sulit dan ketika diberi soal mereka merasa bisa mengerjakannya. $40 \%$ masuk dalam kategori kurang berminat menjawab sebanyak 4 orang disebabkan oleh mereka senang belajar dengan guru matematika, materi pelajaran matematika baginya sangat sulit, mereka juga beranggapan materi pelajaran matematika sangat sulit dipahami. 10\% masuk dalam kategori berminat menjawab sebanyak 1 orang disebabkan siswa sering membaca buku, senang belajar dengan guru 
matematika, jika ada soal yang tidak bisa dikerjakan maka mereka akan bertanya kepada aorang lain, mereka juga selalu mengulang pelajaran dirumah, mereka mudah memahami materi yang diberikan guru, serta ketika diberi soal mereka merasa bisa mengerjakannya.

\section{IMPLIKASI}

Implikasi merupakan arah dan tindak lanjut dari makna yang terkandung dalam temuan penelitian. Dengan demikian penelitian ini memiliki implikasi terdapat minat belajar siswa selama pandemi covid-19 di Lingkungan III kelurahan Padang Masiang Kecamatan Barus masuk dalam kategori cukup berminat, oleh karena itu agar kedepannya siswa lebih memfokuskan dan lebih meningkatkan minat belajarnya, apabila mengalami kesulitan dan merasa bosan serta tidak semangat dalam belajar ada baiknya bertanya kepada teman atau orang yang lebih ahli dalam bidang itu.

\section{SARAN}

Berdasarkan kesimpulan dan implikasi hasil penelitian yang telah dikemukakan diatas, maka peneliti menyarankan hal-hal sebagai berikut:

1. Bagi siswa agar diharapkan untuk lebih meningkatkan minat belajarnya terhadap pelajaran matematika selama pandemi covid-19.

2. Bagi orang tua siswa diharapkan untuk selalu membantu menumbuhkan minat belajar dan selalu mengawasi siswa dalam belajar baik masa normal ataupun selama pandemi covid-19.

3. Bagi guru diharapkan memberikan bimbingan yang lebih kepada siswa sehingga dapat menumbuhkan minat belajar siswa selama pandemi covid-19.

4. Bagi peneliti lain sebagai bahan masukan dalam membuat karya ilmiah yang lebih baik lagi.

\section{DAFTAR PUSTAKA}

Abdillah, Leon A. 2020. Stigma Terhadap Orang Positif COVID-19. http://eprints.binadarma.ac.id/4163/. Diakses pada bulan Juni 2020.

Arikunto, Suharsimi. 2014. Prosedur Penelitian, Suatu Pendekatan Praktik. Jakarta: Rineka Cipta.

Dimyati dan Mudjiono. 2010. Belajar Dan pembelajaran.Jakarta: Rineka Cipta.

Faturrohman, Muhammad dan Sulistyorini. 2014. Belajar dan pemeblajaran: Meningkatkan Mutu Pembelajaran sesuai Standar Nasional. Kalimedia.

Friantini, Rizki Nugraha dan Winata, Rahmat. 2019. Analisis Minat Belajar Pad Pembelajaran Matematika. Jurnal Pendidikan Matematika Indonesia. Volume IV; 6-11.

Detik News. https://news.detik.com/berita/d-4943950/latar-belakang-virus-corona-perkembangan-hinngaisu-terkini diakses pada tanggal 10 Februari 202

Miles, Matthew B dan Huberman, A.Michel. 1992. Analisis Data Kualitatif. Jakarata: Penerbit Universitas Indonesia.

Nurhasanah, Siti dan Sobandi, A. 2016. Minat Belajar Sebagai Determinan Hasil Belajar Siswa. Jurnal Pendidkan Manajemen Perkantoran. Volume I Tahun 2016; 128-135.

Nurkholis. 2020. Dampak Pandemi Novel-Corona Virus Disiase (Covid-19) Terhadap Psikologi Dan Pendidikan Serta Kebijakan Pemerintah. Jurnal PGSD. Volume VI Tahun 2020.

Oktavia, Dhea Nada., Sutisnawati, Astri., \& Maula, Luthfi Hamdani. 2020. Analisis Minat Belajar Matematika Berbasis Daring Pada Siswa Sekolah Dasar Di Kelas Rendah. DIKDAS MATAPPA: Jurnal Ilmu Pendidikan Dasar. Volume II Tahun 2020.

Pakpahan, Roidha dan Fitriani, Yuni. 2020. Analisa Pemanfaatan Teknologi Informasi Dalam Pembelajaran Jarak Jauh Di Tengah Pandemi Virus Corona Covid-19. JISAMAR: Journal Of Information System, Applied, Manajement, Accounting And Research. Volume IV Tahun 2020.

Rangkuti, Ahmad Nizar. 2014. Metode penelitian Pendidikan Pendekatan Kuantitatif, Kualitatif, PTK, dan Penelitian Pengembangan. Bandung: Citapustaka Media.

Ricardo dan Meilani,Rini Intansari. 2017. Impak Minat Dan Motivasi Belajar Terhadap Hasil Belajar Siswa. Jurnal Pendidkan Manajemen Perkantoran. Volume II Tahun 2017; 188-201.

Riyanto, Yatim. 2012. Pradigma Baru Pemeblajaran. Jakarta: Kencana.

Setiawan, Adib Rifqi. 2020. Lembar Kegiatan Literasi Saintifik Untuk Pembelajran Jarak Jauh Topik Penyakit Coronavirus 2019 (COVID-19). EDUKATIF: Jurnal Ilmu Pendidika. Volume II Tahun 2020; 28-37.

Sholikhah, Zidayatush., Kartana, Tri Jaka., \& Utami, Wikan Budi. 2018. Efektifitas Model Open Ended Terhadap Prestasi Belajar Matematika Ditinjau Dari Kreativitas Siswa. Jurnal Program Studi Pendidikan Matematika FKIP-UNIKU. Volume IV; 35-46

Silalahi, Ulber. 2012. Metode Penelitian Sosial. Bandung: Refika Aditama.

Simbolon, Naeklan. 2013. Faktor-Faktor Yang Mempengaruhi Minat Belajar Peserta Didik. E.S.J: Elementary School Jurnal PGSD FIP UNIMED. Volume II Tahun 2013. 
ISSN. 2621-9832

JURNAL MathEdu (Mathematic Education Journal) http://journal.ipts.ac.id/index.php/MathEdu Vol. 4 No. 2 Juli 2021

Simanjuntak, D. R., Ritonga, M. N., \& Harahap, M. S. (2020). ANALISIS KESULITAN BELAJAR SISWA MELAKSANAKAN PEMBELAJARAN SECARA DARING SELAMA MASA PANDEMI COVID-19 Oleh. Mathematic Education Journal)MathEdu, 3(3), 142-146. http://journal.ipts.ac.id/index.php/

Slameto. 2015. Belajar Dan Faktor-Faktor Yang Mempengaruhinya. Jakarta: Rineka Cipta.

Sugiyono. 2018. Metode Penelitian Pendidikan (pendekatan Kuantitatif, Kualitatif, dan R\&D). Bandung: Alfabeta.

WHO (World Health Organization). 2020. Cara Pencegahan Virus Corona COVID-19 Menurut Anjuran WHO. https://ilovelife.co.id/blog/cara-pencegahan-virus-corona-covid-19-menurut-anjuran/. Diakses pada tanggal 10 Februari 2021.

Yerianto, Ahmat. Penyakit Virus Corona (Covid-19) Gejala, Penyebab, Pengobatan, Dan Cara Pencegahan Virus Corona. https://m.klikdokter.com/penyakit/Coronavirus. Diakses pada tanggal 11 Februari 2021. 